Agro-Science Journal of Tropical Agriculture, Food, Environment and Extension Volume 16 Number 3 (September 2017) pp. 9 - 14

ISSN 1119-7455

\title{
ECONOMIC ANALYSIS OF BEEF MARKETING IN AWKA NORTH LOCAL GOVERNMENT AREA OF ANAMBRA STATE, NIGERIA.
}

\author{
Nse-Nelson, F.A. Osondu, K.R. Oke, U.R. and Chux, J.C. \\ Department of Agricultural Economics, Michael Okpara University of Agriculture Umudike, Abia \\ State, Nigeria. \\ email: floxynse@gmail.com.
}

\begin{abstract}
This study examined the marketing of beef in Awka North Local Government Area of Anambra State. The objectives of this study were to describe the socio-economic characteristics of beef marketers, ascertain the costs and return of beef marketing, determine the factors affecting revenue derived from beef marketing and examine problems faced by beef marketers in the study area. Four towns in the local government were purposively selected because these towns have large markets with many beef marketers. Fifteen beef marketers were randomly selected from each of the four markets giving a total of sixty respondents. Data were analyzed using descriptive statistic, net return analysis and multiple regression analysis. Result showed that $40 \%$ of the beef marketers were within the age of $31-40$ years, $64 \%$ were females and a high percentage of them (76\%) were married. Majority of the respondents (60\%) acquired only primary school education and 70\% of the respondents had household size of between $1-5$ persons. $A$ net return of $\$ 501.50 \mathrm{k}$ per kilogram of beef was obtained showing that beef marketing was profitable in the study area. The multiple regression analysis showed age, educational level, storage cost, marketing experience and cost of purchase were significant variables which affect beef marketing. The major constraints faced by the beef marketers were lack of fund, high transportation cost and inadequate storage facilities. Beef marketers should take advantage of economies of scale to ensure profitability and by extension, improved livelihood and sustainability of the business.
\end{abstract}

Keywords: Beef marketing, economic analysis, net returns, constraints, Awka North

\section{INTRODUCTION}

The growth of a country's population is usually accompanied by increases in the demands for the basic necessities of life including water, food and shelter. This is the case for the unrestricted increases in the demand for protein rich food items of animal origin (Ugwumba and Chukwuji, 2010). Beesf is used generally to refer to the meat of a cow, bull, young bull, bullock or steer even if the tenderness and flavour may vary greatly. It is a rich source of protein, lipid, vitamins, phosphorous and other substances that are nutritionally important (Emokaro and Amadasun, 2012). The need for protein in the diet of human beings cannot be underestimated as different categories of individuals need protein for growth and development, regeneration of ageing and building of worn out tissue. Beef, out of the various sources of animal protein consumed is a major source of protein in an average Nigerian family. This is necessitated due to its wide acceptability devoid of religious and sociocultural constraints (Oladejo, 2012). Considering the high importance of beef in the diet of man as a source of protein and its wide acceptance, its marketing should be examined. Marketing encompasses all business activities associated with transfer of a product from the producers to consumers (Uhls and Kohls, 2002). Marketing is the process of performing market research, selling products and services to customers and promoting them via advertising to further enhance sales. Marketing efficiency is often used in evaluating the performance of the marketing process. Efficiency is a measure of performance of a system, it may be marketing or production performance. Marketing efficiency is measured by the input-output ratio, hence an efficient market is obtained when the ratio value of the input throughout the system is maximized. The value of marketing efficiency ranges from zero (0) to infinity and less than $100 \%$ efficiency shows that the market is efficient while over $100 \%$ efficiency shows excess profit (Olukosi and Isito, 1990).

Emokaro and Ekunwe (2009) reported that beef marketing provides the largest livestock market in Nigeria. The industry provides employment for a large number of the population, including butchers, abattoir owners, meat shop owners, transporters and other marketers. This is 
aside the millions of Nigerians who make their livelihood from beef enterprises as cattle grazers/nomads, butchers, beef producers/processors, veterinary services providers, marketers, transporters and providers of several ancillary services. Government agencies also realize a lot of revenue from the beef industry through various forms of levies, market charges and direct taxation. A lot of families depend on the business of beef marketing for sustenance. Those involved in the beef marketing also depend on it as a source of livelihood (Ekunwe et al., 2008). The supply of cattle and its product have been declining while the demand has been increasing, the short fall in supply of cattle has often been linked to the high cost of cattle marketing, because the cattle are brought from the Northern part of the country to the South, usually there is high cost of transporting the cattle considering the long distance that the traders have to travel with them (Mafimisebi et al., 2013). Omotosho (2001) explained that beef market is imperfect, based on his findings from a related research. One factor that may be responsible could be the fact that a uniform standard of measurement of meat based on weight, which would have enhanced the marketing. He observed that there is the basic problem of the unequal bargaining power of various links in the marketing chain. There has been a continuous problem of price and sales volume fluctuation over the years as a result of marketing inefficiencies (Erhabor, et al.,2008).

It is known that most agricultural are bulky, perishable and highly prone to microbial attack which leads to deterioration in quality and finally results in the spoilage and wastage of these products. An analysis of the effect of beef marketing of this nature is intended to identify possible ways to reduce the cost involved in the business and improve the livelihood of the persons involved in beef marketing, and as such ensure the sustainability of the business. The specific objectives of this study were to describe the socio-economic characteristics of beef marketers, ascertain the net returns and marketing efficiency of beef marketing, determine the factors affecting revenue derived from beef marketing and examine problems faced by beef marketers in the study area.

\section{MATERIALS AND METHODS}

The study was conducted in Awka North Local Government Area of Anambra State, Nigeria. It is located at latitude $6^{0} 15^{1} \mathrm{~N}$ and $7^{0} 10^{1} \mathrm{E}$ and longitude $6.250^{\circ} \mathrm{N}$ and $7.167^{\circ} \mathrm{E}$. It occupies a total land area of 340 square kilometers, with a population of 112,608 people (NPC, 2006). The area lies within the tropical rainforest belt; hence it experience bimodal peak of rainfall. The area is predominantly occupied by farmers as it supports a wide range of farming, while its green vegetation also supports livestock farming. Towns that make up the Local Government Area are AwbaOfemili, Ugbene, Ebenebe, Achalla, Urum, Amanise, Amanasa, Amanuke, IsuAniocha, Mgbakwu, Ugbenu. A two-stage sampling procedure was employed to select the sample size needed for the study. In the first stage, four towns in the Local Government Area, namely; Isu Aniocha, Achalla, Ugbenu and Mgbakwu were purposively selected because these towns have large markets with many beef marketers. The sampling frame consists of all the beef marketers in the selected markets. Finally 15 beef marketers each were selected through simple random selection, from these big markets in these four towns to evaluate beef marketing. This gives a total of 60 respondents for the study. Primary data used for this study were collected through the use of a well-structured questionnaire administered to respondents and through oral interviews. Data were analyzed using descriptive and inferential statistics such as frequency counts and percentages, net return analysis and multiple regression analysis. Five point likert-type scale was used to measure constraints faced by beef marketers.

The net return of the beef marketers is the profit made in the course of the marketing and it is calculate as

$$
\mathrm{NR}=\mathrm{TR}-\mathrm{TC}
$$

Where:

$\mathrm{NR}=$ Net return

$\mathrm{TR}=$ Total revenue (Price of quantity sold)

$\mathrm{TC}=$ Total cost (Fixed cost and Variable cost)

Factors affecting beef marketing was analyzed using multiple regression analysis model.

The model is expressed as

$$
\mathrm{Y}=\mathrm{F}\left(\mathrm{X}_{1}, \mathrm{X}_{2}, \mathrm{X}_{3}, \mathrm{X}_{4}, \mathrm{X}_{5}, \mathrm{X}_{6}, \mathrm{X}_{7}\right)
$$

Or more explicitly,

$$
\mathrm{Y}=\mathrm{b}_{0}+\mathrm{b}_{1} \mathrm{X}_{1}+\mathrm{b}_{2} \mathrm{X}_{2}+\mathrm{b}_{3} \mathrm{X}_{3}+\mathrm{b}_{4} \mathrm{X}_{4}+\mathrm{b}_{5}
$$

$\mathrm{X}_{5}+\mathrm{b}_{6} \mathrm{X}_{6}+\mathrm{b}_{7} \mathrm{X}_{7}+\mu_{\mathrm{i}}$

Where;

$\mathrm{Y}=\mathrm{Revenue}$ (naira)

$\mathrm{X}_{1}=$ Age of respondents (years)

$\mathrm{X}_{2}=$ Educational level of respondents (years)

$\mathrm{X}_{3}=$ Household size (number)

$\mathrm{X}_{4}=$ Marketing experience (years)

$\mathrm{X}_{5}=$ storage cost (naira)

$\mathrm{X}_{6}=$ cost of transportation (naira)

$\mathrm{X}_{7}=$ Cost of beef purchased (naira)

$\mathrm{U}_{\mathrm{i}}=$ error term.

The four functional forms of the multiple regression model are stated as follows

Linear: $\mathrm{Y}=\mathrm{b}_{0}+\mathrm{b}_{1} \mathrm{x}_{1}+\mathrm{b}_{2} \mathrm{x}_{2}+\mathrm{b}_{3} \mathrm{x}_{3}+\mathrm{b}_{4} \mathrm{x}_{4}+\mathrm{b}_{5} \mathrm{x}_{5}+\mathrm{b}_{6} \mathrm{x}_{6}+\mathrm{b}_{7}$ $\mathrm{x}_{7}+\mathrm{e} \quad$.(4)

Exponential $\quad \log Y=b_{0}+b_{1} x_{1}+b_{2} x_{2}+b_{3} x_{3}+b_{4} x_{4}$ :

$+\ldots \mathrm{b}_{7} \mathrm{x}_{7}+\mathrm{e}$

Semi- $\log : Y=b_{0}+b_{1} \log x_{1}+b_{2} \log x_{2}+b_{3} \log x_{3}+$ 
Nse-Nelson, F.A. Osondu, K.R. Oke, U.R. and Chux, J.C.

$\mathrm{b}_{4} \log \mathrm{x}_{4}+\mathrm{b}_{7} \log \mathrm{x}_{7}+\log \mathrm{e}$

Double-log: $\log Y=b_{0}+b_{1} \log x_{1}+b_{2} \log x_{2}+b_{3} \log x_{3}+$ $\mathrm{b}_{7} \log \mathrm{x}_{7}+\log \mathrm{e}$

Four functional forms of the regression model were used which are the linear, exponential, semi-log and double log. Semi-log functional form of the model was chosen as the lead equation based on the number of significant variables, the value of the $\mathrm{R}^{2}$ (coefficient of multiple determination), F-ratio and conformation of the variables to a priori expectation. The five point likert scale is an ordinal level of measurement as adopted by Emokaro and Egbudion (2014). Responses to the various constraints were scored in a way that the response indicating the most serious constraint was given the highest score of five. These responses were grouped into five thus: very serious $=5$, serious $=4$, moderately serious $=3$, least serious $=2$, not serious $=1$. For a given constraint, the mean was computed by summing the score on each item and then dividing by the total number of responses. Any mean that is less than three $(x<3)$ indicates that the particular constraint is not very serious while any mean equal or greater than three $(x>3)$ indicates that the particular constraint is serious.

\section{RESULTS AND DISCUSSION Socio-economic characteristics of the respondents}

The Socio-economic characteristics of the beef marketers are presented in Table 1 below. The result showed that $40 \%$ of the respondents were within the age bracket of $31-40$ and $36 \%$ of the respondents were between the ages of 21-30 those above 51 years of age were not recorded. This result implies that majority of the beef marketers were young and were within the active age. This is in consonance with Emokaro and Egbodion (2014) who reported that most the people involved in beef marketing were averaged aged women who are vibrant and energetic and can positively influence marketing. The result also showed that $64 \%$ of beef marketers were females while $36 \%$ were males. This showed that women dominate in beef marketing in the study area. This observation may be due to more of the men being engaged in other related activities such as transportation, loading and off loading, market park activities amongst others. Table 1 also showed that $60 \%$ of the respondents had primary school education while $33.33 \%$ of them acquired secondary education and $6.67 \%$ acquired tertiary education. It shows that most beef marketers in the study area had at least primary education and could access formal sources of information that could improve their business.
This is a desirable development as it will enhance the adoption of new innovation; provide readability consciousness and awareness all of which can enable taking of business decisions that will enhance market performance. This result is similar to the findings by Adeoye et al., (2009) where it was stated that education improves the ability of marketers to make accurate marketing decisions. Majority (76\%) of the respondents in the study area were married. Singles accounted for $13.33 \%$ of the population and $10 \%$ were widows. It can be inferred that since majority of the respondents were married, they have social obligations to cater for at the household level and this causes their involvement in beef marketing activities to be very serious in order to raise the income required to meet their financial obligations (Mafimisebi et al., 2013).

Thirty five percent of the respondents had marketing experience of 10-15 years while $15 \%$ of them had marketing experience of $1-5$ years. Experience plays very important role in every human endeavour. It is the basis of success and progress in business (Mafimisebi and Okunmadewa, 2006). When there is lack of experience, the likely outcomes have been shown to be low income for marketers. (Mafimisebi et al., 2012). The result in Table 1 also showed that the household size of 1-5 persons was recorded for $70 \%$ of the respondents while $6-10$ persons were recorded for $30 \%$ of the respondents. The implication of this is that the respondents had manageable family sizes which may assure marketers of extra helping hands in their ventures.

\section{Cost and return analysis}

The net return analysis of the beef marketers is presented in Table 2 below. From the result presented in Table 2, the beef marketers incurred a total variable cost which includes cost of purchase, transportation cost, storage and packaging cost of $\$ 1099.93$ and generated revenue of $\$ 1601.93$ per kilogram of beef. Net return of $\$ 501.50$ per kilogram of beef was obtained showing that beef marketing was profitable in the study area. Marketing efficiency of 1.45 was realized from the business venture and this means the business was economically efficient in terms of input- output ratio. Marketing effisciency of 1.45 implies that for every $\$ 1$ invested in the business, $\$ 1.45 \mathrm{k}$ was realized as net return. 
Table 1: Socio-economic characteristics of the

\begin{tabular}{lll} 
respondents & & \\
\hline Age & $\begin{array}{l}\text { Frequency } \\
60)\end{array}$ & $\begin{array}{l}(\mathrm{n}- \\
\text { Percentage } \\
(\%)\end{array}$ \\
\hline $11-20$ & - & - \\
$21-30$ & 22 & 36.67 \\
$31-40$ & 24 & 40.00 \\
$41-50$ & 14 & 23.33 \\
$51-60$ & - & - \\
Gender & & \\
Female & 38 & 64 \\
Male & 22 & 36 \\
Level of $\quad$ Formal & & \\
Education & & \\
No formal education & 0 & 0 \\
Primary & 36 & 60 \\
Secondary & 20 & 33.33 \\
Tertiary & 4 & 6.67 \\
Marital Status & & \\
Single & 8 & 13.33 \\
Married & 46 & 76.67 \\
Widow & 6 & 10 \\
Marketing Experience & & \\
$1-5$ & 9 & 15 \\
$6-10$ & 15 & 21.33 \\
$11-15$ & 20 & 35 \\
16-20 & 16 & 28.67 \\
$21-25$ & - & - \\
Household size & & 66 \\
$\mathbf{1 - 5}$ & 40 & 30 \\
$\mathbf{6 - 1 0}$ & 18 & 4 \\
$\mathbf{1 1 - 1 5}$ & 2 & \\
\hline Source: Field survey, & 2016 & \\
& &
\end{tabular}

Table 2: Costs and return analysis of the beef marketers

\begin{tabular}{ll}
\hline Variables & Value $\mathrm{N}($ per $\mathrm{kg})$ \\
\hline Cost of beef purchased & 1040.67 \\
Transportation cost & 32.50 \\
Storage cost & 15.76 \\
Packaging & 5.00 \\
Miscellaneous (other costs) & 6.00 \\
Total variable cost & 1099.93 \\
Total revenue & 1601.43 \\
Net return (profit) & 501.5 \\
Marketing efficiency & 1.45 \\
\hline Source: Field survey, 2016 &
\end{tabular}

Factors that affect beef marketing in Awka North L.G.A

The analysis of factors affecting beef marketing is presented in Table 3 below. Table 3 showed the result of the regression analysis of factors affecting beef marketing in the study area. Semi$\log$ functional form was chosen as the lead equation for the analysis based on conformity with a priori expectation of signs, magnitude of coefficients, overall significance of the functional form (F-statistics) as well as the explanatory power of the variables $\left(\mathrm{R}^{2}\right)$ included in the model.
The value of $R^{2}$ (coefficient of multiple determination) was 0.571 indicating that the independent variables accounted for $57.1 \%$ variation in the revenue from beef marketing while the remaining $43.9 \%$ not explained is attributed to other variables not included in the model. The F- statistics was significant at 5\% and indicated that the model is of good fit. Age, educational level and marketing experience were significant and positively related to the revenue. The higher the educational attainment of an individual, equipped him with better skill and knowledge to maximise resource and hence, make more revenue in business. This also agrees with (Obasi, 2013) who found out that, better education placed marketers at advantage as it enlightened them on how to adapt new marketing strategies. It is generally believed that the more the experience of a market participant in marketing, the greater the efficiency of the marketing system. Obasi (2008) stipulated that increased marketing experience help marketers adapt to new positive marketing strategies.

Storage cost, transportation cost and cost of purchase were significant but negatively related to revenue from beef marketing. This implies that these costs negatively affect the revenue of the beef marketers. The higher the marketing cost incurred in the business, the lesser the return from the business. This is in consonance with Emokaro and Egbodion (2014) and also Erhabor et al., (2008) where they found out that variable costs were the major determinants that affect income realizable from beef marketing. An increase in these costs will bring about decrease in the revenue of the marketers while a decrease in these costs will increase the revenue.

\section{Problems associated with beef marketing}

The constraints faced by the beef marketers in the study area are shown in the table below. The study revealed several problems militating against the effective and efficient marketing of beef in the study area. Inadequate fund is the most serious problem of beef marketing (mean =4.52). Obasi (2008) opined that inadequate fund is the major reason for small scale marketing. This inadequate fund may have been necessitated by the low level of education and lack of knowledge on how to access such. High transportation cost is also a serious constraint ( mean $=4.40)$. 
Table 3: Factors affecting beef marketing in the study Awka North L.G.A.

\begin{tabular}{lllll}
\hline Variables & Linear & Exponential & Semi- log+ & Double- log \\
\hline Constant & $115.829(4.982)^{* * *}$ & $4.846(35.069)^{* * *}$ & $-320.258(-1.700)^{*}$ & $2.495(2.230)^{*}$ \\
Age & $-0.002(-2.491)^{* *}$ & $-0.012(-0.910)$ & $0.003(4.322)^{* * *}$ & $0.083(3.017)^{* *}$ \\
Educational level & $-1.077 \mathrm{E}-005(-0.658)$ & $0.000(2.076)^{* *}$ & $1.784(4.322)^{* * *}$ & $-0.007(-0.335)$ \\
Household size & $0.000(-338)$ & $-1.182 \mathrm{E}-006(26.605)^{* * *}$ & $1.128(0.136)$ & $0.005(0.101)$ \\
Storage cost & $-0.146(-5.284)^{* * *}$ & $-0.001(-5.098)^{* * *}$ & $-49.386(-6.350)^{* * *}$ & $-0.286(-.196)^{* * *}$ \\
Marketing exp. & $0.024(1.034)$ & $0.000(0.931)$ & $50.720(3.065)^{* * *}$ & $0.024(0.518)$ \\
Transport cost & $-0.001(-1.485)$ & $3.630 \mathrm{E}-006(-1.077)$ & $-19.973(-1.557)$ & $-0.095(-1.244)$ \\
Cost of purchase & & $-0.001(-3.740)^{* * *}$ & $-.551(-3.661)^{* * *}$ & $-7027.477(-3.634)^{* * *}$ \\
& $-7.085(-3.682)^{* * *}$ & & & 0.571 \\
$\mathrm{R}^{2}$ & 0.556 & 0.531 & 0.522 & 0.495 \\
Adjusted $\mathrm{R}^{2}$ & 0.506 & 0.478 & $11.749 * *$ & $10.657 * *$ \\
F-ratio & $11.068 * * *$ & $9.991 * * *$ & & \\
\hline Source: Feld & & &
\end{tabular}

Source: Field survey data, 2016

Note: $(* * *)=$ significant at $1 \%,(* *)=$ significant at $5 \%,(*)=$ significant at $10 \%$. Figures in parenthesis are the $\mathrm{t}-\mathrm{values}$.

Ekunwe, P.A., Emokaro, C.O.O., Ihenyen, J.O. and

Table 4: Problems Faced by Beef Marketers in Awka North L.G.A, Anambra State

\begin{tabular}{lcll}
\hline Problems & Mean & $\begin{array}{l}\text { Standard } \\
\text { Deviation }\end{array}$ & Rank \\
\hline Inadequate fund & 4.52 & 0.56 & 1 \\
High transportation cost & 4.40 & 0.48 & 2 \\
High Storage cost & 4.32 & 0.44 & 3 \\
Spoilage & 3.21 & 0.40 & 4 \\
Poor storage facilities & 2.95 & 0.38 & 5 \\
High marketing charges & 2.54 & 0.34 & 6 \\
\hline Source: Field survey data 2016 & &
\end{tabular}

This implies that the higher the transportation cost, the lower their net revenue. According to Okpara (2012), transportation cost is an expense and encroaches in the revenue of the marketer. There is high risk of spoilage due to erratic power supply. This facilitates spoilage of what is not sold. Inadequate storage facilities lead to quick deterioration of the beef.

\section{CONCLUSION}

It has been shown in this study that beef is mainly marketed in Awka north L.G.A. by married, fairly educated and experienced female marketers still in their active age of production. This finding has policy implication with respect to age and gender perspective, since this aspect of the economy is critical to the economic base of the individual family unit predominantly run by the female folk. The economic security of women (through increased income generation) has been advocated based on the critical role they play on the household economy. Efforts should be made to make credit facilities available and sensitize marketers of beef on the need to invest wisely on critical aspect of beef marketing cost so as to ensure increased net return and by extension, improved livelihood and sustainability of the business.

\section{REFERENCES}

Adeoye, I.B., Odeleye, O.M.O., Babalola, S.O. and Afolayan, SO. (2009). Economic analysis of Tomato losses in Ibadan Metropolis, Oyo State, Nigeria. National Horticultural Research Institute publication, Idi-Ishin, Ibadan. Idoshi, No.1. Pp.89.
Alufohai, G.O.(2008). An Analysis of Egg Marketing in Benin City, Edo State, Nigeria. Farm Management Association of Nigeria (FAMAN) $22^{\text {nd }}$ Annual National Conference Proceedings, held in Markurdi, Pp. 331-337.

Emokaro, C.O. and Amadasun, O.J. (2012). Analysis of Beef marketing in Benin city, Nigeria. Journal of Agriculture, Forestry and Fisheries, 8: (3). 2432.

Emokaro, C. O. and Egbodion, J.(2014). Effect of marketing cost on marketing margin realizable from beef sales in Benin City, Nigeria. American Journal of Experimental Agriculture, 4: (2). 215224.

Emokaro, C. O. and Ekunwe, P. A.(2009). Determinants of Income Realizable from Snail Marketing in Benin City, Nigeria. Journal of Agriculture, Forestry an Fisheries, 10: (2). 35-38.

Erhabor, P. O.,Ahmadu, J and Ingawa, S. A. (2008). Efficiency of beef marketing in Edo State, Nigeria. In: Aiyedun, E.A, Idisi, P.O., Nmadu, J. $\mathrm{N}$, editors. Proceedings of the $10^{\text {th }}$ Annual National Conference of the Nigerian Association of Agricultural Economists (NAAE). University of Abuja. Pp.570 - 577.

Mafimisebi, T.E. and Okunmadewa, F.Y. (2006). Are Middlemen Really Exploitative? Empirical Evidence from the Sun-dried Fish Market in Southwest, Nigeria. In: Rebuilding Fisheri in an Uncertain Environment.CD-ROM of the 13th Biennial Conference of the International Institute of Fisheries Economics and Trade. Pp. I2.

Mafimisebi. T.E, Oguntade, A.E, Fajeminsin N.A and Ayelari P.O. (2012). Local Knowledge and Socio Economic Determinants of Traditional Medicines' Utilization in Livestock Health Managements in South West Nigeria. Journal of Ethnobiology and Ethnomedicine, 6: (21). 42-48.

Mafimisebi. T.E, Bobola, O.M and Mafimisebi, O.E. (2013). Fundamentals of cattle marketing in Southwest, Nigeria: Analyzing market intermediaries, price formation and yield Performance: Invited paper presented at the $4^{\text {th }}$ International conference of the African Association of Agricultural Economics, Hammamet,Tunisia. Pp.17 - 30 .

National Population Commission (NPC) (2006). Population distribution by sex, state, LGAs and Senatorial district. 2006 census priority tables (vol. 3).Pp. 105. 
Obasi, I.O. (2008). Structure, conduct and performance of rice marketing in Abia State. An unpublished M.Sc thesis in the Department of Agricultural Economics, Michael Okpara University of Agriculture Umudike, Nigeria. Pp.71.

Obasi, I.O. and Amaechi, E.O. (2013). Efficiency of Poultry Marketers in Owerri Municipal, Imo State, Nigeria. Research Journal of Agriculture and Environmental Management, 2: (8).197-201.

Okpara, B.O. (2012). "Analysis of Fish Marketing by Women in Ebonyi State Nigeria". Unpublished M.Sc. Thesis, Department of Agricultural Economics, Michael Okpara University of Agriculture Umudike, Nigeria. Pp 64.

Oladejo, J. A. (2012). Profitability of beef marketing in Illorin East Local Government area of Kwara State. Prime Research on Biotechnology, prime journal.org, 2: (3).47-52.
Olukosi J. O. And S. U. Isito (1990). Introduction to Agricultural Marketing and Price Principles and Application Cautions. Living books series G. V publication, Abuja.

Omotosho, J.K. (2001). Probability of dried meat trade in Ibadan Metropolis. An unpublished P.G.D. Thesis submitted to the department of Agricultural Economics and Extension, Ladoke Akintola University of Technology, Ogbomosho, Oyo State, Nigeria.

Uhls, J.N. and Kohls, R.L.(2002). Marketing of Agricultural Products, $9^{\text {th }}$ edition. Prentice Hall.

Ugwumba, C.O.A and Chukwuji, C.O. (2010) The Economics of Catfish Production in Anambra State, Nigeria: A profit function approach. Journal of Agriculture and Social Sciences. 6: (2).105-109. 